ments), to the vases, and to the terra-cottas, deserve the most careful reading; the student could scarcely find anything more worthy of inward digestion.

It is only to be regretted that the high price of this work ( $\operatorname{some} £ 18$ ) places it out of the reach of all but the wealthy. But it is a necessity to archaeological libraries.

P. G.

\title{
Denkmäler Griechischer und Römischer Sculptur. Von H. BrunN. Munich : in progress.
}

THIs great work, which is to be completed in 80 parts, should be here mentioned, though criticism may be deferred until it has further advanced towards completion. The object is to furnish students-but above all, teachers and lecturers-with photographs on a large scale of typical works of ancient sculpture. Such plates as have as yet appeared (3 parts) have no accompanying text. We can only judge, therefore, of two things : selection and execution. We notice with great satisfaction that Prof. Brunn usually selects for his plates objects which are not geverally known by means of casts-notably sculptures recently found at Athens, Epidaurus, and elsewhere. This is clearly the right principle, so long as nothing is selected merely because it is new. The execution has been entrusted to Bruckmann, of Munich, and so far he has been very successful. Even in museums where casts of the objects photographed exist, these photographs are by no means superfluous; they escape the vulgarity and deadness of casts, while their superior portability gives them great advantages for class-work. When Prof. Benndorf brings out his promised new series of prints of vases, to place beside these photographs of sculpture, the apparat of the teacher of archaeology will be greatly improved.

P. G.

Les Musées d'Athènes : en reproduction phototypique de Rhomaïdes Frères. Texte de P. Cavpadias. Athens. 1886, \&c.

OF this quadrilingual work only two parts are yet issued. The text is not of much importance, being confined to a short deseription of the plates. The main object of the work is to publish to the world, by means of these latter, some of the more important of the archaeological treasures now coming to light in such numbers in the excavations in Greece. Most of the sixteen photographic plates which have so far appeared contain representations of the female figures of archaic style recently found near the Erechtheum (Journ. Hell. Stud. viii. p. 159). Some of these have still more recently been represented in the original colouring in the plates of the Athenian Ephemeris. Besides, there are representations of the Moschophorus of the Acropolis, of two bronze heads, and fragments of a horseman-all from the same interesting site.

P. G.

Die Akropolis. Von. A. Bötricher. Bèrlin, 1887.

Die Akropolis, we need scarcely say, is the Acropolis of Athens. Dr. Bötticher gives in this book a clear and popular and well-illustrated account of the history of this celebrated citadel, especially as it has been revealed by recent excavation. Those who are acquainted with the author's book on Olympia will scarcely need to be told that this work is well-arranged, clearly written, and based on the study of 